\title{
HARMONIZATION OF THE NATIONAL AND INTERNATIONAL LAW ON THE USAGE SETTINGS OF NATURAL RESOURCES IN THE TERRITORY OF THE REPUBLIC OF INDONESIA
}

\author{
Munsharif Abdul Chalim \\ UNISSULA Semarang, Central Java, Indonesia \\ munsharif.abdul@gmail.com
}

\begin{abstract}
This paper aims to examine the suitability between national law and international law in the regulation of natural resource use. In this paper used the normative juridical method, with primary data contains laws relating directly to international law, while secondary data in the form of journals or library references. The result of this research is to obtained that adjustment of the national legal system into a global legal system, it makes positive law becomes harmonious and uniform (harmony of law) and the adjustment of certain legal norms into a unity of global norm which later can be used as a means of dispute resolution. Harmonious and uniform can be achieved if global harmony of decisions are the same. The legal arrangements of the archipelago countries as reflected in the three points raised by the archipelago supporters which reflect the principles of the regime on waters of the archipelago as practiced by Indonesia and the Philippines. In these circumstances the only effort that can be made to unite the opinions in order to get a clear pattern is the consultation with various groups, both between themselves and between groups.
\end{abstract}

Keywords: harmonization of law, national law, international law, natural resources.

\section{A. INTRODUCTION}

Legal harmonization is an adjustment or synchronization between laws and regulations within a country, treaties or conventions applicable to states, as well as between the legislation of a country and inter-state agreements/ conventions. Adjustment or legal synchronization in this case includes the purpose, certainty, fairness and benefit of the law itself. Without this harmonization can cause the absence of certainty which certainly can cause problems in society.

The development of international law largely rises from Western Europe countries which is concern on legal system of society or nations which its legal concepts and principles derive from the national legal system. Furthermore, it has emerged from the Roman legal system and concept and kept developed through international customs as the source. National laws that have universal values can be accepted by the international community that can be used as a principle or rule of law. Through the primacy of national law, it is expected that the role of national law can provide the concept or principles of international law as a contribution to develop international law.

Harmonization of international and national law is a pluralism harmonization of the legal systems in the international legal system. It is design to harmonize the legal system which can be agreed by all countries in implementing international agreements. Harmonization of national and international law is an urgent need to be done in order to realize harmony, balance, and consistency in national legislation system that ensures legal certainty and protection which based on justice and truth. The legal certainty and protection of justice and truth is the purpose of harmonization, even in the progressive legal paradigm, justice can be marginalized to support the existence of humanity, truth and justice ${ }^{1}$. Thus, a systemic harmonization

\footnotetext{
Gunarto, 2011, Rekonstruksi konsep Kebebasan Berserikat Melaui Serikat Pekerja Pada Hubungan Industrial Berbasis Nilai Keadilan Menuju Kesejahteraan Pekerja (Ringkasan Disertasi), Program Doktor IImu Hukum Undip Semarang, p. 9
} 
law concept can be developed, as a basic concept and a grand design in the process of enforcing legislation that refers both to a philosophical value. This philosophical value gives a sense of justice and truth as well as a sociological value in accordance with cultural values which is applicable in a nation, further, it can not be separated from the consideration of economic value and juridical.

There are two views on submission to international law, the first view is voluntarism. It states that application of international law or the existence of international law is based on the state. The second is objectivism, which considers the existence or enforcement of international law apart from the will of the state. The existence of this different view leads to the emergence of different viewpoints, the view of voluntarism will result in the existence of international and national law as two sets of laws that coexist and separate. On the other hand, objectivism sees that international and national law is the same place with legal instruments; it is closely related to legal issues or the hierarchy between the two sets of laws.

Since no doctrinal position seems to encompass all the facts, it is likely that this controversy will continue indefinitely. Practice suggests that, in fact a mixture of international law supremacy, municipal law supremacy, and coordination of legal systems exists. When, for example, an international tribunal finds that municipal law conflict with international law, it will override the municipal law ${ }^{2}$. As long as there is no doctrine covering all the facts, it is possible that the controversy of international law with national law will continue, where in practice it shows that in reality, the supremacy of international law with national law in the legal system will remain.

"It is in the practice of national courts that the relationship of international law to municipal law is of fundamental importance. Lacking adequate enforcement device of its own, the international community must rely largely upon

2 Greco-Bulgarian "Communities" advisory opinion of the permanent Court of International Justice, 1930, which the Court stated : international law that in the relations between powers who are contracting parties to a treaty. the governmental organs of the separate states to give effect to its norms ${ }^{3}$."

In the practice of national courts, the relationship between international and national law is very important. The lack of adequate law enforcement devices, the international community must rely on the government from various countries to provide a norm effect. Adherents of the harmonization theory D.P.D. Cornell states that international law and national law must be interpreted in such a way that both have harmony. The existence of international law and national law is in a harmonious relationship, but it does not mean that there will never be a link between them. Should there be a connection between the two, it should be preferred one of the two, but must still be interpreted in a harmonious relationship atmosphere.

As has been described above, the harmonization of law intends to create the benefit, certainty and justice. The law is created with the aim of upholding justice. The law continues to survive and be maintained because it is necessary for the establishment of justice ${ }^{4}$. However, the fact is not all law enforcement activities by itself have upheld justice ${ }^{5}$. So that with the harmonization of international and national law is expected to provide a justice, especially for the Indonesian government itself in the regulation of natural resources. As mandated by Article 33 paragraph (3) and (4) of the 1945 Constitution of the State of the Republic of Indonesia:

Paragraph (3): The earth and water and natural resources contained therein are controlled by the state and used for the greatest prosperity of the people.

Paragraph (4): The national economy is organized on the basis of economic democracy with the principles of togetherness, fair efficiency, sustainability, environmental insight, independence, and by maintaining a balance of progress and national economic unity. ${ }^{6}$

3 MacLeod v. United'States, (1930), The statute should be construed in the light of the purpose of the Government to act within the limitation of the principles of international law, the observance of which is so essential to the peace and harmony of nations.

4 Ali Mansyur, 2010, Pranata Hukum \& Penegakkannya di Indonesia, Unissula Press, Semarang, p.49 ibid

6 The Constitution of Republic of Indonesia Article 33 paragrapf (3) and (4). 
The birth of United Nations Convention on the Law Sea under the provisions of the New Law Sea is applied. Thus, Indonesia is an archipelago country that is seen as a unified whole between the islands and its waters ${ }^{7}$. Two-thirds or approximately $70 \%$ of Indonesia's territory consists of the sea, the remaining one third or approximately $30 \%$ consists of land or earth, which contains natural resources. We realize that the sea is rich in priceless mineral goods, which is expected to meet the needs of the world if the mineral resources in the mainland are not sufficient or completely exhausted. This encourages coastal states, including Indonesia to undertake exploration and exploitation of marine areas including the territory of the continental shelf that becomes its jurisdiction. The sources of wealth present in the marine areas and especially in the continental shelf area are so great and when it is processed and utilized optimally, it will bring benefit the human in the world. Not only Indonesia alone, but also approximately $70 \%$ of the total surface area of the earth is composed of the sea, and in addition to the widespread percentage is a fact, that now the greater role of the sea, namely as a source of food, energy and raw materials ${ }^{8}$. Therefore, the existence of the potential of marine resources and on the seabed and the underlying soils which is called as the continental shelf needs further regulation, either through international or national law.

We can not deny that the development of law in Indonesia especially in the development of legal substance is still far from the hope to meet the needs and aspirations of Indonesian society. In the implementation of the plan and the formation of quantitative is more prominent than the consideration of the quality of the legislation issued. ${ }^{9}$ Full control and exclusive rights over 7 ST Munadjat Danusaputro; K awasan Baskom Pasifik Menghadapi Gelomban g Perkembangan Internasional : Pengembang a $n$ Studi Wilayah Kawasan Asia Pasifik (Bunga Rampai), p. 148.

8 Frans E, Likadja dan Daniel F Bessie; 1988, Hukum Laut dan Undang-Undang Pe $r$ ikanan, Ghalia Indonesia, Jakarta, p.10.

9 Hasil penelitian yang dilakukan oleh Bappenas pada tahun 2004 memperlihatkan bahwa dalam kurun waktu 1990 - 2004, dari sejumlah 383 peraturan pemerintah yang diamanatk a oleh 211 undangundang hanya sebanyak $60 \mathrm{PP}$ atau hanya 15 persen yang dapat diselesaikan. the natural resources found in the area of the continental shelf and ownership exist in coastal countries, where the meaning of this natural wealth is the mineral and resource lifeless which can be found more on the seabed and the land beneath it, as well as organisms including species Sedenter. An organism attached to the seabed and underlying soils, in accordance with the sound of Article 1 sub b and Article 2 of Law no. 1 Year $1973 .{ }^{10}$

The continental shelf is not only a geographical and geological phenomenon, but also a very strategic economic phenomenon, because of the potential mineral wealth contained in it. This economic phenomenon is largely determined by technological advances in the field of exploration and exploitation. With this background problem, it is necessary to harmonize the arrangement, that is the arrangement of the utilization of natural resources in the continental shelf region, the above description of the background, the question arises how the Harmonization of National Law and International Law on the Regulation of Natural Resources Utilization in the continental shelf region of the Republic Indonesia? And how to regulate the utilization of natural resource potential in the continental shelf region of Indonesia with other countries?

\section{B. Discussion}

1. Harmonization of International and National Law of the Regulation of Natural Resources Utilization in the Continental Shelf of the Republic of Indonesia

To observe the development and formation of the law of the sea including the question of regulating the continental shelf region, it is necessary to study and analyze the interests underlying the attitude of the state as a member or part of the international community "11. Developing countries will endeavor to exercise control over the sea for the expansion of jurisdiction to protect their interests, let

10 P.Joko Subagyo; 2002, Hukum Laut Indonesia, Rineka Cipta, Jakarta, p.41.

11 Ramlan, 2006, Hukum Laut Internasional, Universitas Jambi, Jambi, p. 28. 
alone advancing technological advances encourage the desire to utilize natural resources that would benefit a country. Therefore, to implement the wishes and regulate the interests of international countries as well as in order to avoid overlap between these interests then the international maritime law conventions was convened. Where the last successful implementation of the Convention of the Law of the United Nations (UN) 1982 which has resulted in the United Nations Convention on the Law of the Sea (UNCLOS) III, which among others regulates maritime boundaries including territorial sea boundaries (Territorial Sea), Exclusive Economic Zones, and so Boundaries of the Continental Shelf associated with the discussion in the writing of this dissertation.

The continental shelf has only geographical and geological insight. Geographically and geologically the continental shelf is defined as the plateform or seabed area situated between the shallow seabed and the point where the seabed decreases sharply or steeply, which is called the continental shelf. One of the countries that have ratified the 1982 UN Sea Law Convention is Indonesia. Indonesia is the world's most internationally recognized archipelago.

The natural resources contained in the continental shelf consist of minerals and other non-living resources located on the seabed and underlying soils, including living organisms that are classified into sedimentary species that are organisms at harvestable levels in a state that can not be Moves and lies on the seafloor or underneath it or can only move if there is physical contact that remains with the seabed or underneath (eg lobsters). While Mochtar Kusumaatmadja, said besides the sedenter above there are sentary species of living organism such as seaweed and other herbs, sponges, coral enichoderm, mollucs. For nonrenewable resources contained in the subsoil under the seabed according to the type of coating comprising:

- continental shelf ie petroleum, natural gas, sulfur, mineral harvest, coal, diamonds;

- continental slope ie phosphor;

- Abbysal plain and deep seabeds there are $25 \%$ manganese, $15 \%$ iron, cobalt, nickel, copper.

Seabed in Indonesia contain mineral potential in the form of gold, silver, timble, tin, copper, nickel, oil and natural gas $70 \%$ from oil and gas basin. It is estimated that Indonesia has approximately 60 basins. It contains an estimated petroleum potential of nearly 9.1 billion barrels. Natural gas potential is 230 trillion cubic feet equivalent. It is a great potential for us Indonesia to be utilized and manage the existing marine natural resources, governance is carried out continent for the welfare of its citizens living near the coastal area.

The concept of the continental shelf was introduced by the United States at the International Law of the Sea Convention in 1901. The submission was a strategy for dealing with archipelagic states proposing the concept of an archipelagic country, and in order to facilitate the interest of his country to explore non-biological natural resources (oil and gas) ) Which is very potential in the continental shelf. The problems that exist, due to the unclear concept of the continental shelf boundary in UNCLOS I 1901, then this makes the Convention on Sea Law III of $19 \wedge r$, the issue of the continental shelfbeone importantagenda.

The 1982 United Nations Convention on the Law of the Sea (1982 - United Nations Convention on the Law of the Sea) has granted Indonesia recognition in the form of an archipelagic country. This international recognition, followed up with the issuance of Law no. 17 of 1985 on the Ratification of the United Nations Convention on the Law of the Sea 1985. Since the enactment of this law on 31 December 1985, Indonesia was bound by the 1982 UN Naval Convention (UNCLOS 
1982). This recognition is very important for Indonesia that has the most islands in the world, the existing problems, how the management of natural resources that can provide a welfare for the people around the coast of the Unitary Republic of Indonesia.

In Indonesia in the context of harmonization of law, it can be seen in Presidential Decree Number $1 \wedge \wedge$ of $199 \wedge$, Article $r$ which reads as follows; "In the framework of harmonization, rounding and consolidation of conceptions to be outlined in the Draft Law, the Minister or the head of the drafting body of the drafting advisor of the Draft Law shall first calculate the conception with the Minister of Justice and other Ministers and other related Institution Leaders".

L.M. Gandhi stated that, in "Harmonization of the Law to Responsive Law" states that; "Harmonization within the law includes the adjustment of legislation, government decisions, judges' decisions, legal systems and legal principles with the aim of enhancing legal unity that can create legal certainty, justice and equality, the utility and clarity of the law, without obscuring and sacrificing pluralism law". 12

The formulation of the ideal steps taken in the harmonization of the legal system is as proposed by L. Friedmann that it is necessary to make adjustments to elements of the legal order applicable within the framework of the legal system of the national (legal system) which includes legal substance components, Along with its legal structure and legal culture component. Thus the harmonization of the national legal system (as well as in relation to international law) involves linking the three components of the legal system within the framework of the national legal system."

\footnotetext{
12 M. Gandhi, "Harmonisasi Hukum Menuju Hukum Yang Responsif", Makalah, yang disampaikan pada Pidato Pengukuhan Guru Besar Tetap FH-UI, 1995, dalam Mop. Hasan Wargakusumah, dkk, 1996/1997, Op, Cit, p. 28-29

13 Ibid., p. 107
}

Furthermore, consider the national legal system as input is to take into account the existence of legal system which concerns on elements of legal substance. The rule of law that consists of the external legal order of legislation, non-written law including customary law and jurisprudence as well as the internal legal order of the underlying legal principles, the legal structure and its legal structure, consisting of various institutional bodies or public institutions with its officials. With the enactment of the Convention on the Law of the Sea of 1958, Indonesia has arranged specifically the regulation of the territory of the content landscape through Act No. 1 of 1973. Furthermore, with the enactment of the 1982 UN Naval Law Convention (UNCLOS 1982) specifically on the territory of its continental shelf or has not adopted the 1982 United Nations Convention on the Law of the Sea into law, and has just ratified the convention. Substantially Indonesia since 1973 has a law on regulating the use of its continental shelf region. With the enactment of the 1982 UN Naval Convention (UNCLOS) Indonesia has not transmitted or has specifically adopted the regulation of its continental shelf territory. But until now in practice in the issue of regulating the use of the continental shelf region of Indonesia apply its arrangement through the 1982 UN Law of the Sea Convention. With the enactment of the 1982 United Nations Convention Indonesia has not set $s p$ e cifically on the regulation of the use of continental shelf territory, so substantially Law Number 1 Year 1973 is still in force, therefore there is a need for harmonization of the law of the Republic of Indonesia horizontally (between laws) regarding the regulation of the utilization of natural resources in the continental shelf region of RI. It is expected that through horizontal harmonization can be achieved vertical harmonization (between national law 
and international law) in regulating the utilization of natural resources in the continental shelf region to achieve a justice value.

2. Regulation of utilization of natural resource potential in continental shelf areas of RI with other countries

Principles concerning the legal arrangements of archipelago countries as reflected in the three points proposed by the archipelago supporters above reflect the principles of the regime on waters of the archipelago as practiced by Indonesia and the Philippines. In these circumstances the only effort that can be made to unite the opinions is a clear pattern of thought, it can be drawn by consultation between the various groups between themselves and between groups. Many different interests intercept each other, one country often belonging to several groups. The consultations of the group are held through; called "contact groups", ie groups consisting of exponents of different groups. When the autumn trial of 1973 had not yet been concluded a draft convention on the Law of the Sea, there was not even a general description of the establishment of the participating countries or the groups contained in the court.

It was also decided that the opening of the conference be divided into two sessions, the first session was discussing procedures and events while the actual session decided to be held in Caracas was held several months later. In accordance with the decision of the Preparatory Committee of the Conference in the last session mentioned above, the Third Assembly of the Law of the Sea was held in New York in December of 1973 to discuss conference and conference arrangements. Since conference events are not a hardship, most of the sessions are used to discuss the order to be used in the Third Sea Law Conference.

The result of the first trial of the Third Sea Law convention in New York on this order was very interesting. After a long debate the conference made several decisions, the most important of which were two decisions on order: (1) accepting both the rules of the Sea Law Which is based on the arrangements of UN conferences in accordance with the habits contained in UN conferences. This order indicates commonly recognized texts, such as organizing the session sessions in plenary sessions and committees of the Committee; The way of voting is a simple majority for decisions in the Committee and the 2/3 majority for decisions of plenary sessions. The rules also contain the usual provisions on how to submit amendments and proposals.

The second decision taken in this New York trial is that the accepted order will not be used unless it is urgent. The conference held in Caracas decided to use unanimously voice decision. This second decision which essentially overrides the rules of order that have been accepted in the first decision, called the Gentleman Agreement.

There are considerations that encourage conference participants to make decisions about this Gentleman Agreement, the most important of all is that all the participants of the New York assembly together know that in the course of the development of the conference at that time it was considered impossible to use ordinary rules, given that differences Between participating countries is still too far away and that there is no clear picture of what participant wants.

As an explanation it may be pointed out here that part of the difficulty is due to the ever increasing number of participants with the newly freed countries, the conversation often crude back because newcomers often start talking about things that have already been discussed and have reached a point of maturity far enough.

Without an absolute rejection of the archipelagic conception proposed by India 
this group of island states insists that this issue is a separate and separate issue requiring arrangements that must be distinguished from the legal arrangements of the archipelagic state. This stance was taken because it was conveyed that most of the conference participants who could support the conception of an archipelagic state did not approve of the adoption of this conception to the archipelago that was part of a country.

The countries which raise objection are from developing countries, namely, on the African continent. is that if the application of the principle of the island nation is expanded on the archipelago rather than a country then it may lead to the application of this conception in other circumstances such as the archipelago Hawaii which is part of the United States.

Another development during the Caracas trial was the emergence of another country in gin to apply the conception of the Bahamas in the Caribbean region. Another development is the desire of several regions in the Pacific Ocean, both independent and in the process of achieving their independence to also apply the conception of an archipelagic state to a group of islands in the Pacific Ocean.

These developments illustrate the difficulties involved in finding satisfactory restrictions on the conceptions of the island nation. The reason is that if this development is allowed to extend then the obvious conception of the island nation can be applied to the island group countries will be blurred, which will undoubtedly reduce the likelihood of receiving the conception of the island nation as part of the current Law of the Sea. On the other hand, we must be careful in making distinctions between an island conception and the conception of other island states because the overly perceived rejection will also result in less support from most conference participants not only from different archipelagic states but Also from his friends. The development that emerged in Caracas concerning the conception of the archipelago resulted in the delegation of Indonesia and other island group members being forced to conduct consultation and lobbying activities with countries with similarly archipelagic conceptions, in order that the conception of an archipelagic state owned by an archipelagic country group Still maintained.

As with the Geneva Sea Law conference, the difficulty in attempting to make the archipelago's conception generally accepted (universal) as a conception of the law of the Sea is that the countries really concerned about this issue are limited in number. In contrast to the conception of the 200-mile economic path that directly concerns the interests of dozens of coastal states, it can not be expected that participants who come to attend the conference by mainly thinking about and fighting for their own interests, to pay too much attention to the conception archipelago state. What is important for the country's archipelagic country's endeavor is to prevent an active challenge to the archipelagic country's conception. For the purposes of supportive state delegations efforts are made to explain the conceptions of the archipelagic country at every opportunity both inside and outside the session. This is done intensively since Indonesia attended the UN Seabed Committee sessions which as it became known since 1971 changed become the Preparatory Committee of the Sea Law conference.

These efforts are even conducted outside of the conference forums such as the sessions of the Asian African Legal Consultative Committee and by each island-state support country in regional meetings held, such as those conducted by Mauritius in the OUA (Organization of United African).

In the business relation of obtaining the support of other countries it should 
be called the Head of Statess business which in every occasion of meeting with the heads of state or head of government of another country, always expresses the issue of Nusantara Insight as one of the important issues for Indonesia.

In addition to efforts made through meetings, officially by diplomatic officials, efforts to spread and instill a sense of the archipelagic concept are also conducted within the academic circles, both in individual contacts and in academic meeting forums, as in the annual meeting held by the Law of Sea Institute, rather than the University of Rhode Island, in Kingston (USA).

Academic contacts and academic forums have a great value, since the conference is attended by not only prominent experts in the maritime law, but also by the highest echelon advisors and officials of governments who took part in the Third Sea Legal Conference.

The stage or degree of crystallization of the participant's attitude to the concepts and principles of the archipelagic country in the form of draft chapters is a difficult stage, since the active form of the articles governing the archipelago state in the convention determines whether states of interest Directly exposed by the conception of this archipelagic country may accept the concrete provisions of it or not. Until then the founding of such good states that approved or rejected was only given in the form of more political statements.

Countries which directly concerned with the principle of an archipelagic can be divided into the following categories:

1. Neighboring countries namely ASEAN members and other neighboring countries including Australia.

2. Countries with fishing and communications interests (telecommunication cable on the seabed). Japan belongs to this group because it has been doing fisheries in Indonesian waters since before the war.
3. Maritime Country. These countries are concerned that maritime traffic is not disrupted. In this group can be entered a country that has a commercial fleet consisting mostly of developed countries, such as countries in Western Europe. In this group the Scandinavian country has a special position because since the Geneva Sea Law conference, these countries pioneered by Norway have always shown a understanding attitude towards the conception of the island nation

4. The great Maritime State has a military strategy importance. Including this group of countries the United States and the Soviet union.

Among these groups the first and special attention is given to neighboring countries, because we can not, however, expect the understanding and support of other participating countries, especially those who are doubtful of the principle of an archipelagic state, if Indonesia's closest neighboring country does not expressly support it.

Any problems with this neighboring country can be solved, most recently with Malaysia with the signature of a Memorandum of Understanding dated July 26, 1976 in Jakarta. With the achievement of the positive and firm support of most of the neighboring countries and whose interests are directly affected by the application of archipelagic country principles, living now solves problems with the United States and the Soviet Union.

Considering that the issues need to be solved are directly related to the interests of this giant state military strategy in the framework of their global strategic conception, the settlement of the problem is difficult and sensitive, but we believe that with persistence and firm stance accompanied by the realism of adversityThis difficulty can be overcome.

From the explanation issued together 
with the proclamation of the President of the United States above, it can be deduced that which encourages the holding of the proclamation above is the need to reserve mineral wealth, especially petroleum for the benefit of the United States and manage its exploitation as well as possible. The action covering an area of 760,000 square miles beneath the surface of the sea was taken after acquiring a belief that the continental shelf adjacent to the United States contained petroleum and other mineral reserves and offshore drilling techniques had reached a level that allowed the extracting of resources - the source of that wealth. As we have seen the above quotation, the power over the "continental shelf" does not affect the nature of the waters above it as the open sea and freedom of shipping traffic.

\section{Conclusion}

From the description can be concluded that Without the harmonization of the legal system, will bring up a situation that can not guarantee legal certainty and can cause disruptio $\mathrm{n}$ in community life, disorder and sense of unprotected. In such a perspective the problem of legal certainty will be perceived as a need that can be realized through the harmonization of the legal system. Formulated in two steps namely the adjustment of the national legal system into a global legal system and thus harmonious and uniform is the law of harmony (law) and the adjustment of certain legal norms into a unified global norm which can later be used as a means Dispute resolution, thus harmonious and uniform in the event of a dispute are global harmony of decisions. The legal arrangements of the archipelagic countries as reflected in the three points raised by the archipelago supporters above reflect the principles of the regime on waters of the archipelago as practiced by Indonesia and the Philippines. In these circumstances the only effort that can be made to unite the opinions so that a clear pattern of thought can be drawn is the consultation between the various groups between themselves and between groups.

In the harmonization of the law especially related to the regulation of the continental shelf region, two things need to be considered, namely the harmonization of the regulatory system and the harmonization of the substance, The law (norms). So that the international law that has been made / negotiated together, can give a sense of justice for all countries of the parties.

\section{BIBLIOGRAPHY}

Ali Mansyur. 2010. Pranata Hukum \& Penegakkannya di Indonesia. Unissula Press. Semarang. Alma Manuputy. et al. 2008. Hukum Internasional, Makasar.

Colombi Ciacchi, A., 2005; "Non-Legislative Harmonisation of Private Law under the European Constitution: The Case of Unfair Suretyships", Oxford and Portland, Oregon: Hart Publishing

Craig P and de Búrca, G. (3rd edn). 2006. "The Harmonisation of European Contract Law Implications for European Private Laws, Business and Legal Practice". Oxford and Portland, Oregon: Hart Publishing

Likadja Frans E dan Daniel F Bessie; 1988, Hukum Laut dan Undang-Undang Perikanan, Ghalia Indonesia, Jakarta,

Ginsburg, T and Cooter RD, 2004. "Leximetrics: Why the Same Laws are Longer in Some Countries than Others", (American Law and Economics Association Annual Meetings

Greco-Bulgarian "Communities" advisory opinion of the permanent Court of International Justice, 1930, which the Court stated : international law that in the relations between powers who are contracting parties to a treaty. 
Gunarto, 2011; Rekonstruksi konsep Kebebasan Berserikat Melalui Serikat Pekerja Pada Hubungan Industrial Berbasis Nilai Keadilan Menuju Kesejahteraan Pekerja (Ringkasan Disertasi), Program Doktor IImu Hukum Undip Semarang

Hesselink, M.; The Ideal of Codification and the Dynamics of Europeanisation: The Dutch Experience in the book by Vogenauer, (2006). "The Harmonization of European Contract Law Implications for European Private Laws, Business and Legal Practice". Oxford and Portland, Oregon: Hart Publishing.

Kusnu Goesniadhie, , 2006. Harmonisasi Hukum Dalam Persfektif perundang-undangan; Lex Specialis Suatu Masalah, (Surabaya; JP Books),

Likadja Frans E dan Daniel F Bessie; 1988, Hukum Laut dan Undang-Undang Perikanan, Ghalia Indonesia, Jakarta,

Mochtar Kusumaatmadja, 1969; Pengambilan Kekayaan Alam Di Dasar Laut dan Tanah Di Bawahnya (Seabed and Subsoil) dan Hukum Internasional, Binacipta, Bandung

M. Gandhi, 1996/1997. "Harmonisasi Hukum Menuju Hukum Yang Responsif”, Makalah, yang disampaikan pada Pidato Pengukuhan Guru Besar Tetap FH-UI, 1995, dalam Moh. Hasan Wargakusumah, dkk,

MacLeod v. United'States, 1930. The statute should be construed in the light of the purpose of the Government to act within the limitation of the principles of international law, the observance of which is so essential to the peace and harmony of nations (Undangundang harus ditafsirkan dengan jelas mengenai tujuan Pemerintah untuk bertindak dalam batasan prinsip-prinsip hukum internasional, dan ketaatan terhadap prinsip-prinsip tersbut begitu penting bagi perdamaian dan harmonisasi bangsa-bangsa),

Menski, W. 2005. “Comparative Law in a Global Context”. London: Cambridge University Press.

Mochtar Kusumaatmadja, 1969. Pengambilan Kekayaan Alam Di Dasar Laut dan Tanah Di Bawahnya (Seabed and Subsoil) dan Hukum Internasional, Binacipta, Bandung

Peter E Nygh, Peter Butt (ed). (1997). "Butterworth Australian LEGAL Dictionary"

P. Joko Subagyo. 2002. Hukum Laut Indonesia. Rineka Cipta. Jakarta

Ramlan. 2006. Hukum Laut Internasional, Universitas Jambi, Jambi.

ST Munadjat Danusaputro; Kawasan Baskom Pasifik Menghadapi Gelombang Perkembangan Internasional : Pengembangan Studi Wilayah Kawasan Asia Pasifik (Bunga Rampai)

Geneva Convention on the Law of the Sea; (Convention 4)

Undang-Undang RI Nomor 17 tahun 1985 tentang Pengesahan United Nations Convention on The Law of The Sea, point 4 mengenai Landas Kontinen.

Undang -Undang Dasar RI Tahun 1945, Pasal 33 ayat (3) dan (4)

United Nations Convention on the Law of the Sea; Article 77 (3) : "The rights of the coastal State over the continental shelf do not depend on occupation, effective or notional, or on any express proclamation". 